\title{
Uzaktan Eğitim Alan Üniversite Öğrencilerinin Sosyal Bulunuşluk ile İşlemsel Uzaklıkları Arasındaki İlişkinin İncelenmesi
}

\section{Investigation of the Relationship Between Social Incidence and Transactional Distance of Students University Receiving Distance Education}

\section{Öz}

\author{
İsmail KARAKUŞ ${ }^{1}$, Tuğba YANPAR YELKEN²
}

Günümüz bilgi çağında bireylerin her yaşta, her yerde ve her konuda öğrenmelerini destekleyen çevrimiçi öğrenmeyle gerçekleşen uzaktan eğitim kavramının önemi üzerinde durulmaktadır. Uzaktan eğitim ortamlarında; bireylerin kendilerini ne derece sosyal ortamlarda hissettiği, sosyal bulunuşluk algısının nasıl olduğu ve fiziksel uzaklıkların iletişimi ne ölçüde etkilediği, işlemsel uzaklıkların bireyler üzerinde nasıl sonuçlarının olduğu önemli bir sorun haline gelmiştir. Yapılan bu araştırmanın amacı, uzaktan eğitim alan üniversite öğrencilerinin sosyal bulunuşluk düzeyleri ile işlemsel uzaklıkları arasındaki ilişkiyi incelemektir. Araştırmada tarama yöntemi modellerinden ilişkisel tarama kullanılmıştır. Veriler 'Sosyal Bulunuşluk Ölçeği' ile 'Işllemsel Uzaklık Ölçeği' kullanılarak elde edilmiştir. Ayrıca araştırmanın amaçlarına yönelik olarak araştırmacı tarafından hazırlanan 'Kişisel Bilgi Formu' da kullanılmıştır. Araştırma, 2018-2019 akademik yılının birinci döneminde Mersin Üniversitesi Sosyal Bilimler Meslek Yüksekokulunda öğrenim gören 607 birinci sınıf öğrencisine uygulanmıştır. Elde edilen bulgulara göre, öğrencilerin sosyal bulunuşlukları ve işlemsel uzaklıkları; cinsiyete, öğrenim türüne, uzaktan eğitim deneyimine, çalışma durumuna ve üniversite öncesi yaşadığı yere göre farklılaşmamakta, öğrenim gördükleri bölüm ve teknolojik yeterlilik düzeylerine göre ise farklılaşmaktadır. Öğrencilerin sosyal bulunuşluk ile işlemsel uzaklık ölçeklerinin değişkenler arasındaki ilişkiye bakıldığında pozitif yönde orta düzeyin üzerinde ve anlamlı bir ilişki olduğu tespit edilmiştir.

Anahtar Kelimeler: işlemsel uzaklık, sosyal bulunuşluk, uzaktan eğitim

\section{Abstract}

In today's information age, the importance of distance education concept which is realized by online learning which supports the learning of individuals in every age, everywhere and in every subject is emphasized. In distance education environments; the extent to which individuals feel themselves in social environments, how the perception of social presence and how physical distances affect communication, and how operative distances have consequences on individuals have become an important problem. The aim of this study is to investigate the relationship between social presence levels and transactional distance of university students who receive distance education. In the study, relational scanning which is one of the scanning method models was used. The data were obtained by using the Social Presence Scale and Transactional Distance Scale. In addition, Personal Information Form 'prepared by the researcher was used for the purposes of the research. The research has been applied to 607 first year students in Mersin University Social Sciences Vocational School in the first semester of 2018-2019 academic year. According to the findings, students' social presence and transactional distances; they do not differ according to gender, type of education, distance education experience, working status and the place they lived before the university, but they differ according to the departments and technological competence levels. When the relationship between social presence and total scores of transactional distance scales was examined, it was determined that there was a positive and moderate relationship.

Keywords: transactional distance, social presence, distance education 


\section{Extended Abstract}

Purpose: The aim of this study was to determine the relationship between social presence levels and transactional distances of university students receiving distance education and their social presence and transactional distances; gender, type of education, distance education experience, working status, pre-university residence, the department and the level of technological competence according to whether they differ or not.

Method: This study is a descriptive study using the survey model to determine the current situation. In the scope of the research, determining the relationship between social presence levels and transactional distance of university students receiving distance education indicates that the research is in the relational screening model of the types of screening models. In the selection of sampling, layer sampling from probability-based sampling methods was used.

The data obtained from the social presence and operational distance scales were analyzed using SPSS 20.0 program. Cronbach Alpha coefficient was used to determine the reliability of the scales. The scores obtained from the scales were tested for normal distribution. In order to test this, "Kolmogorov Testi Smirnov Single Sample Test (KS) coefficients were used. When the result of KS test is examined; It was found that there was no significant difference in social presence total score (SW607 = $0,72, p<.05$ ), but the transactional total score was not significantly different ( $S W 607=0,24, p>.05$ ). Nonparametric tests were used in two groups (Mann Whitney U Test) and more than two groups (Kruskal Wallis Test) (Büyüköztürk, 2013). In the analysis of transactional distance, parametric tests were used in two group comparisons ( $t$ test) and in more than two group comparisons (ANOVA). The Spearman Brown Sequence Difference correlation coefficient was used in the calculation of the relationship between I social presence and transactional distance .

Findings: According to the findings, students' social presence and transactional distances; they do not differ according to gender, type of education, distance education experience, working status and the place they lived before the university, but they differ according to the departments and technological competence levels. When the relationship between social presence and total scores of transactional distance scales was examined, it was determined that there was a positive and moderate relationship.

Conclusion and Discussion: When the results of the study are examined, it is determined that the social presence of the university students receiving distance education is at a medium level. The social existence of the students does not differ according to gender, type of education, distance education experience, working status and the place they lived before the university. When the source of differences is examined; Between tourism travel and logistics, there was a significant difference in favor of office management between tourism travel and office management in favor of logistics.

Transactional distances of university students receiving distance education were found to be moderate. It is observed that the results related to transactional distance are similar to the results related to social presence. The medium level of both social presence and transactional distance is directed to the distance education system; The problems such as the students' feeling alone, not having enough interaction, not being able to affect each other's work and not creating a sharing environment can be explained as not having much effect on students. In other words, it can be said that approximately half of the students studying with the distance education system feel relatively social in these environments and interact with their friends.

The transactional distances of the students do not differ according to gender, type of education, distance education experience, working status and place of residence before university. Transactional distances of students vary according to the department and technological adequacy levels. . When the differences between the departments they read are examined; between office management, accounting-tax and office management in favor of office management in tourism-travel ancestor, in favor of foreign trade between tourism and travel, in favor of business between tourism and tourism, between social services and tourism-travel differences were found. In technological competence; very good with moderate, bad, very bad among the good, good to medium, bad, very bad between the good favor, between the middle bad, very bad between the middle of the favorable difference was found. This situation; As technological competence increases, the operational distance of the students also increases.

When the relationship between social presence and total scores of transactional distance scales were examined, it was found that there was a significant and positive relationship above the intermediate level. According to these results, the concepts of social existence and transactional distance can be considered interrelated. It can be stated that the two concepts are important for each other, they support each other and one increases and the other increases positively. In his international study, Yılmaz (2017) showed that social presence and transactional distances were effective on students and that these concepts were related to each other.

There are also researchers who reach different results. Lowell (2004) in his study, online and concurrent after the course activity, transactional distance perception and students 'social social relations here has been examined, and students' operational distance perception decreases as the social social status is increasing. In other words, it is concluded that there is a negative relationship. 


\section{Giriş}

İnternet teknolojilerinin hızlı bir şekilde gelişmesi ve yaygınlaşmasıyla birlikte uzaktan eğitim ortamları eğitimin vazgeçilmez birer parçası haline gelmiştir. Uzaktan eğitim ortamları, öğretim elemanı ile öğrencilerin farklı ortamlarda bulunsalar bile öğrenme aktivitelerine katılmalarını sağlamaktadır. Ortaya koyduğu bu alternatif yanıyla uzaktan eğitim aktiviteleri günümüzde tercih edilen öğrenme seçeneklerinden biri haline gelmiştir. Eğitimde zaman ve mekân sınırlılıklarını ortadan kaldırması, fırsat eşitliği ve yaşam boyu öğrenmeyi sağlaması gibi faktörlerden dolayı hem örgün hem de yaygın eğitim aşamalarında uzaktan eğitimin önemi ve yaygınlığı giderek artmaktadır (Bozkurt, 2017). Uzaktan eğitim uygulamalarının etkililiği ve verimliliği üzerinde etkili olan motivasyon, geri bildirim, sosyalleşme gibi bazı unsurlar bulunmakta ve bunlardan birini de uzaktan eğitim uygulamalarındaki 'etkileşim' kavramı oluşturmaktadır (Gökmen, Duman ve Horzum, 2016).

Etkileşim araçlarının bir çevrimiçi öğrenme ortamında var olmalarından çok, nasıl kullanıldıkları önemli görülmekte olup (Parker ve Ingram, 2011; Poza, 2011) çevrimiçi öğrenme ortamlarında hem eşzamanlı hem de eşzamanlı olmayan etkileşim araçlarının bulunması önerilmektedir (So ve Brush, 2008; Rockinson, Szapkiw vd.,2010) .Etkileşimin iyi seviyede, doğru yöntem ve araçla, öğrenmeyi sağlayacak ve artıracak nitelikte olması ve etkileşim araçlarının öğrencilerin tercihleri ve bireysel farklılıklarını göz önünde bulundurup derse katıımını arttıracak şekilde hazırlanıp sunulması önemli görülmektedir (Edwards, 2009; So, 2008). Moore (1997) çevrimiçi öğrenme-öğretme süreçlerinde öğrenen-öğretici, öğrenen-öğrenen ve öğrenen-içerik olmak üzere üç tür etkileşimden bahsetmektedir. Geleneksel öğretim etkinliklerinde bulunan etkileşim olanaklarının çevrimiçi öğrenme ortamlarında sınırlı olması sosyalleşmenin çok düşük düzeyde gerçekleştiğini düşündürebilir ama bu noktada Berge (1995) öğrencilere sunulması gereken "sosyal destek" kavramını ortaya atmış bunu da "Çevrimiçi uzaktan öğrenen öğrencilerin diğer öğrencilerle, öğreticiyle ya da diğerleriyle bir araya gelerek genellikle akademik olmayan olaylar üzerinde etkileşime girdikleri ortamın oluşturulmasıdır." şeklinde açıklamıştır. Çevrimiçi öğrenme ortamlarında öğrenenlerin kendilerine sunulan destek hizmetlerini etkileşim amacıyla kullanma sıklıkları arttıkça yalıtılmışlık duygularının azalacağı; buna bağlı olarak sosyal bulunuşluk algılarının artacağı ve daha derin öğrenmelerin gerçekleşeceği düşünülebilir.

Sosyal bulunuşluk algısını Tu ve Mclsaac (2002) "Öğrenen deneyimleri sonucu oluşan topluluk olma duygusunun ölçüsüdür." diye açıklamaktadır. Bu kavramla ilgili; Whiteman (2002) "iletişim sürecine katılırken hissedilen duygu." McLellan (1999) "Diğer öğrencilerle ve öğretim elemanları ile sosyal bir ortamda var olma duygusudur." Leh (2001) "Bireyin sosyal anlamda kendini ortamda hissetmesi." Tu (2000) "Bireylerin farkındalık derecesi." Garrison (1999) "Bireylerin ortamda kendilerini gösterme derecesi." Gunawardena ve Zittle (1997) "Bireyin gerçek bir insan gibi algılanma derecesidir." şeklinde tanımlamışlardır. Christie, Short ve Williams (1976) ise sosyal bulunuşluk algısını, kişilerarası iletişimde bir kişinin gerçek insan olarak algılanış derecesi olarak açıklamış ve ortamın özellikleriyle ilişkilendirmiş, bunun sonucunda da iletişim ortamlarının sosyal bulunuşluk algısının dereceleriyle orantılı olarak çeşitlenebileceğini ve bu çeşitliliğin öğrencilerin etkileşime girme şekillerini etkileyebileceğini öne sürmüşlerdir. Sosyal bulunuşluk algı düzeyini mimiklerin, göz temasının, beden duruşunun, sözsüz iletişimin ve bu yollarla verilen bilgi aktarımının etkileyebileceğini belirtmişlerdir.

$\mathrm{Bu}$ bağlamda çevrimiçi öğrenmede sosyal etkileşim araçlarının nasıl kullanıldığı, etkileşimin ne derece gerçekleştiği ve öğrencilerin sosyal bulunuşluk algılarının nasıl olduğu öğrenmenin etkililiği ve verimliliği açısından önemlidir. Jonassen (1986) öğrencilerin yüz yüze eğitimde olduğu gibi çevrimiçi öğrenme ortamında da aynı iletişim araçlarını kullandıklarında bilgiyi oluştururken farklı yolları tercih ettiklerini ve bireysel farklııklarının öğrenme süreçlerini etkilediğini belirtmiştir. Şimşek (2000) de öğrencilerin bireysel farklılıklarının; ön bilgi, öğrenme stili, güdülenme ve denetim odağı olarak ele alındığını ve bu farklııklar arasında bilişsel (zeka, yetenek, bilişsel/öğrenme stili), duyuşsal (kişilik yapısı, ilgileri, kaygı düzeyi, denetim odağı), sosyal (akran ilişkileri, aile yapısı, ahlaki gelişimleri) ve fizyolojik (yaşı, cinsiyeti, bilgi işleme kapasitesi) farklılıkların yer aldığını ifade etmiştir. Bu farklılıklar bireyler arasında oluşabilecek iletişimi ve sosyal ilişkiyi de etkileyebilmektedir. Bu noktada öğretici ve öğrenci arasında birtakım iletişimsel boşluklar oluşabilir ayrıca çevrimiçi ortamlarda fiziksel uzaklıklar da göz önünde bulundurulursa bu durum daha da derinleşebilir çünkü uzaktan eğitimdeki fiziksel uzaklık, öğretici ve öğrenci arasında bazı iletişim engellerine yol açabilecek bir durum olup bireyi de psikolojik olarak etkileyebilir (Elcil ve Şahiner, 2014). Bunun bir sonucu olarak öğretici ve öğrenci arasında yanlış anlaşılmalar, diyalog kurmada başarısızlıklar olabilmekte, psikolojik ve iletişimsel boşluklara bağı olarak da işlemsel uzaklık algısı oluşabilmektedir.

"işlemsel uzaklık" kuramı Moore (1983) tarafından uzaktan eğitimle ilgili problemlere ilişkin çözüm arayışlarının sonrasında ortaya çıkmıştır. Bu kavramı öğreticiler ve öğrenciler arasındaki fiziksel uzaklıktan kaynaklanan iletişim ve 
anlaşılma ile ilgili bir boşluk olarak tanımlamaktadır (Moore ve Kearsley 2011). İşlemsel uzaklık kuramının, uzaklık ve özerklik olmak üzere iki farklı boyutu bulunmaktadır. Uzaklık boyutu, karşııklı etkileşim imkanı sunan eğitimin 'diyalog' bileşeni ile öğrencinin ihtiyaçları üzerinde duran 'yapı' bileşenlerinden oluşur. Özerklik boyutu ise dersin hedeflerinin, öğrenme etkinliklerinin ve değerlendirme kriterlerinin belirlenmesinde öğrencinin katılımını açıklamaktadır (Horzum, 2007). Zhang'ın (2003) ortaya koyduğu çalışmalar işlemsel uzaklık kuramının yapılandırmacı ve sosyal öğrenme kuramları ile yakından ilişkili olduğunu göstermektedir. İşlemsel uzaklık algısını; öğrencilerin çevrimiçi derslere etkin katılımına engel olan, öğrenciler ile öğrenme ortamı ve onun bileşenleri (öğretmen, diğer öğrenciler, ders materyalleri, derste kullanılan teknoloji) arasındaki sosyal, psikolojik, duygusal ve fiziksel bir uzaklık olarak açıklamaktadır (Zhang, 2003).

Bu bağlamda çevrimiçi öğrenme ortamlarında öğrencilerin akademik beklentilerinin yanı sıra sosyal, psikolojik ve duygusal beklentilerinin de karşılanması önemli bir sorun haline gelmiştir. Kılıç-Çakmak, Cebi ve Kan (2014) yaptıkları çalışmada çevrimiçi ortamlarda sosyal bulunuşlukta belirlenen alt boyutları duygusal ifadeler, etkileşim ve aidiyet duygusu şeklinde belirlemiştir. Duygusal iletişimde yakınlık, bağııık, samimiyet, açıklık, duygu ve düşüncelerin ifade edilmesi önemlidir. Karşılıklı etkileşim, bireylerin öğrenme etkinliklerini şekillendirmelerine yardımcı olurken, bireyleri tanımayı, kurulan sosyal ilişkilerin gelişmesini sağlamaktadır (Garrison, Anderson ve Archer, 2000). Bireylerin kendilerini daha rahat ifade edebilmeleri bir gruba ait hissedebilmeleriyle mümkün olup öğrencilerin öğrenme ortamına daha istekli katılmaları, bilgi ve deneyimlerini daha rahat paylaşabilmeleri, sosyal ve duygusal anlamda doyuma ulaşmaları sosyal bulunuşluk algılarının artmasıyla ilişkilidir (Üstündağ, 2012).

Rovai (2002) bir topluluk duygusunun oluşmasında sosyal bulunuşluk ve işlemsel uzaklık kavramlarının önemli olduğunu belirtmiştir. Bu bağlamdan hareketle çevrimiçi öğrenme ortamlarında sosyal bulunuşluk ile işlemsel uzaklık, öğrencileri psiko-sosyal açıdan etkileyen, öğrenmelerini doğrudan şekillendiren ve birbiriyle ilişkili olduğu düşünülen kavramlar olarak karşımıza çıkmaktadır. Ayrıca bireylerin hem sosyal bulunuşluklarının hem de işlemsel uzaklıklarının cinsiyete, öğrenim gördükleri bölüme, öğrenim türüne, uzaktan eğitim deneyimine, teknolojik yeterlik düzeylerine, çalışma durumuna ve üniversite öncesi yaşadığı yere göre farklılaşabileceği düşünülmektedir.

Bu araştırmada çevrimiçi destek ortamlarında öğrencilerin diğer bireylerle ve öğretmenleriyle sosyal ortamda var olma algısı belirlenerek sosyal bulunuşlukları ve bireylerin ortamdaki iletişimsel durumları tespit edilerek işlemsel uzaklıkları ortaya konulacaktır. Ayrıca öğrencilerin sosyal bulunuşluk ve işlemsel uzaklıkları arasında ilişki olup olmadığı ve bu iki değişkenin cinsiyet, bölüm, öğrenim türü, uzaktan eğitim deneyimi, teknolojik yeterlik düzeyi, çalışma durumu ve üniversite öncesi yaşanılan yere göre farklılaşıp farklılaşmama durumları tespit edilmeye çalışılacaktır. Günümüzde uzaktan eğitimin yaygınlaşması ve bireylerin bu eğitime yönelmeleriyle birlikte öğrencilerin çevrimiçi öğrenme ortamlarında derse aktif katılımı, kendilerini rahat hissetmeleri, sosyal ilişki içinde olmaları ve etkili iletişim kurabilmeleri önemli bir hal almıştır. Bu bağlamda sosyal bulunuşluk ve işlemsel uzaklık kavramları arasındaki ilişkinin incelenmesinin alan yazına katkı sunacağı düşünülmektedir. Türkiye 'de de alan yazın incelendiğinde sosyal bulunuşluk ve işlemsel uzaklığın bir arada ele alındığı herhangi bir çalışmaya rastlanılmamış olması çalışmayı önemli kılmaktadır. Ayrıca çalışmanın bu konuyla alakalı araştırma yapacak bireylere fayda sağlaması, dijital çağın ve bilgi toplumunun gerekli kıldığı bireylerde farkındalık oluşturması, güncel olan bu kavramların ilkelerini tanıtması açısından önemli olduğu düşünülmektedir.

Bu araştırmanın amacı uzaktan eğitim alan üniversite öğrencilerinin sosyal bulunuşluk düzeyleri ile işlemsel uzaklıkları arasındaki ilişkinin belirlenmesi ve çeşitli değişkenlere göre farklılaşıp farklılaşmadığının incelenmesidir. $\mathrm{Bu}$ amaç doğrultusunda ana problem ve alt problemlere cevap aranmıştır: Uzaktan eğitim alan üniversite öğrencilerinin sosyal bulunuşluk düzeyleri ile işlemsel uzaklıkları arasındaki ilişkinin belirlenmesi ana problem olup alt problemler de aşağıda yer almaktadır:

1. Uzaktan eğitim alan üniversite öğrencilerinin sosyal bulunuşlukları ne düzeydedir?

2. Uzaktan eğitim alan üniversite öğrencilerinin sosyal bulunuşlukları:

2.1. Cinsiyete

2.2. Öğrenim gördükleri bölüme

2.3. Öğrenim türüne

2.4. Uzaktan eğitim deneyimine

2.5. Teknolojik yeterlik düzeyine

2.6. Çalışma durumuna

2.7. Üniversite öncesi yaşadığı yere göre farklılaşmakta mıdır? 
3. Uzaktan eğitim alan üniversite öğrencilerinin işlemsel uzaklıkları ne düzeydedir?

4. Uzaktan eğitim alan üniversite öğrencilerinin işlemsel uzaklıkları:

4.1.Cinsiyete

4.2.Öğrenim gördükleri bölüme

4.3.Öğrenim türüne

4.4.Uzaktan eğitim deneyimine

4.5.Teknolojik yeterlik düzeyine

4.6. Çalışma durumuna

4.7.Üniversite öncesi yaşadığı yere göre farklılaşmakta mıdır?

5. Uzaktan eğitim alan üniversite öğrencilerinin sosyal bulunuşluk düzeyleri ile işlemsel uzaklıkları arasındaki ilişki ne düzeydedir?

\section{Yöntem}

Bu çalışma, var olan durumu saptamak amacıyla tarama (survey) modeli kullanılarak yapılan betimsel bir çalışmadır. Tarama modelleri, nesneler, olay ve olgular, durumlar ve kişiler ile ilgili her türlü verinin tamamının gözden geçirilmesidir. Bu modelde, araştıılan olguya dayanan veriler toparlanır, sınıflandırılır, düzenlenir ve çözümlenir (Şimşek, 2012).

Araştırma kapsamında, uzaktan eğitim alan üniversite öğrencilerinin sosyal bulunuşluk düzeyleri ile işlemsel uzaklıkları arasındaki ilişkinin belirlenmesi, araştırmanın tarama modeli çeşitlerinden ilişkisel tarama modelinde olduğunu gösterir. iliş̧isel tarama modeli ise, iki veya daha fazla değişken arasında değişim varlığını ve/veya seviyesini tespit etmeyi amaçlayan araştırma yaklaşımıdır (Karasar, 2012).

\section{Evren ve örneklem}

Bu araştırma, 2018-2019 akademik yılında Mersin Üniversitesi Sosyal Bilimler Meslek Yüksekokulunda dokuz bölümde öğrenim gören 607 birinci sınıf öğrencisi üzerinden yürütülmüştür. Örneklem seçiminde tüm bölümlerin araştırmaya yansımasını görmek için olasılık temelli örnekleme yöntemlerinden tabaka örnekleme kullanılmıştır. Tabaka örnekleme, sınırları belli bir evrende alt grupların var olduğu koşulda kullanılmakta olup bu örneklem modelinde dikkat edilmesi gereken nokta, evreni kendi içinde saf ve benzeşik bir olgu şeklinde kabullenmek yerine evren içindeki alt grupların varlığından yola çıkarak evren üzerinde çalışmaktır. Her bir bölüm evrenin alt tabakaları olarak düşünülmüş ve örneklemler her alt tabakadan basit tesadüfi yöntemle seçilmiştir. Böylece toplam örneklem içinde her bölümün eşit düzeyde veya evrendeki oranı ölçüsünde temsil edilmesine çalışılmıştır (Yıldırım ve Şimşek, 2013). Ayrıca örneklem sayısı belirlenirken Cohen, Manion ve Morrison'un (2000) çalışmasında yer verdiği örneklem tablosundan yararlanılmış olup evrendeki toplam sayı 1089, Cohen, Manion ve Morrison'un \%99 güven aralığına göre olması gereken asgari sayı 414 ve bu araştırmada ulaşılan örneklem sayısı 607'dir.

Katılımcıların 273'ü kadın, (\%45,0); 334'ü erkektir (\%55,0). Öğrencilerin 96'sı (\% 15,8) Büro Yönetimi, 110'u $(\% 18,1)$ Dış Ticaret, 30’u $(\% 4,9)$ Iş̧letme, 43'ü $(\% 7,1)$ Lojistik, 82'si $(\% 13,5)$ Muhasebe ve Vergi, 43'ü $(\% 7,1)$ Pazarlama, 91'i (\%15) Sosyal Hizmetler, 23'ü $(\% 3,8)$ Turizm ve Otel, 89'u $(\% 14,7)$ Turizm ve Seyahat bölümünde okumaktadır. 263 'ü $(\% 43,3)$ birinci öğretim, 344'ü $(\% 56,7)$ ikinci öğretimde öğrenim görmektedir. Katılımcıların 58'inin $(\% 9,6)$ daha öncesinden uzaktan eğitim deneyimi varken 549 'unun $(\% 90,4)$ uzaktan eğitim deneyimi yoktur. Öğrencilerin $66^{\prime}$ sının $(\% 10,9)$ teknolojik yeterlik düzeyi çok iyi, $175^{\prime}$ inin $(\% 28,8)$ iyi, 206'sının $(33,9)$ orta, 93'ünün $(\% 15,3)$ kötü, 67'sinin $(\% 11,0)$ ise çok kötü düzeyde olduğu tespit edilmiştir. Öğrencilerin 192 'si $(\% 31,6)$ herhangi bir işte çalışmaktayken 415 'i $(\% 68,4)$ herhangi bir işte çalışmamaktadır. Üniversite öncesinde katılımcıların 287 'si $(\% 47,3)$ büyükşehirlerde, 97 'si $(\% 16,0)$ il merkezlerinde, 158 'i $(\% 26,0)$ ilçe merkezlerinde ve $65^{\prime} \mathrm{i}(\% 10,7)$ de belde veya köylerde yaşamaktadır.

\section{Veri toplama araçları}

Kişisel Bilgi Formu: Uzaktan eğitim alan öğrencilerin kişisel bilgilerini öğrenmek amacıyla araştırmacı tarafından oluşturulmuştur. Bu bilgi formunda çalışmanın hedefine uygun olarak öğrencilerin cinsiyeti, öğrenim gördükleri bölümü, öğrenim türü, öncesinden uzaktan eğitim deneyiminin olup olmaması, teknolojik yeterlik düzeyi, üniversite öncesi yaşadıkları yer ve çalışma durumu hakkında bilgiler toplanmıştır.

Sosyal Bulunuşluk Ölçeği: Kang, Choi ve Park (2007) tarafından geliştirilen, Olpak ve Kılıç-Çakmak (2009) tarafından Türkçeye uyarlanan ölçek; ortak bulunuşluk 5, etkileme 7 ve kaynaştırma ile ilgili 7 madde olmak üzere 3 
faktör ve 19 maddeden oluşmaktadır. Ölçek maddelerinin tamamı olumlu ifadelerden oluşmaktadır. Bireyler ölçekte belirtilen her ifadeye ilişkin katılma düzeylerini beşli likert tipinde "hiç katılmıyorum (1)" , "katılmıyorum (2)" , "emin değilim (3)" , "katılıyorum (4)" ve "tamamen katılıyorum (5) şeklinde belirtmiştir. Ölçeğin Cronbach alfa değerleri ortak bulunuşluk .79, etkileme .86 ve kaynaştırma da .91 olarak bulunmuştur. Ölçeğin tamamı için hesaplanan alfa değeri .94 'tür. Bu araştırmada ise sosyal bulunuşluk ile ilgili güvenirlik değerleri sırasıyla; ortak bulunuşluk .77, etkileme .84, kaynaştırma .90 ve toplam ölçek için ise .93 olarak bulunmuştur.

İşlemsel Uzaklık Ölçeği: Zhang (2003) tarafından geliştirilip Yılmaz ve Keser (2015) tarafından Türkçeye uyarlanmış, 5 faktör ve 38 maddeden oluşmakta ve "hiç katılmıyorum (1)", "katılmıyorum (2)", "emin değilim (3)", "katılıyorum (4)" ve "tamamen katılıyorum (5)" şeklinde beşli likert tipi bir derecelendirmeye sahiptir. İşlemsel uzaklık ölçeği; öğrenci-arayüz, öğrenci-içerik, öğrenci-öğretmen, öğrenci-öğrenci ve öğrenci-ortam etkileşimine ilişkin öğrenci algıları olarak beş alt boyuttan oluşmaktadır. Ölçekteki 38 maddeden; 1 ile 8 arasındaki maddeler öğrenci-arayüz, 9 ile 14 arasındaki maddeler öğrenci-içerik, 15 ile 20 arasındaki maddeler öğrenci-öğretmen, 21 ile 31 arasındaki maddeler öğrenci-öğrenci ve 32 ile 38 arasındaki maddeler de öğrenci-ortam etkileşimine ilişkin öğrenci algılarını ölçmekte olup ayrıca 1, 6, 8, 10, 16 ve 37. maddeler de ters puanlanmıştır. Ölçekten elde edilen puanların yüksek çıkması bireyin uzaklık algısının düşük olduğunu, yani öğrenci-arayüz, öğrenci-içerik, öğrenci-öğretmen, öğrenci-öğrenci ve öğrenciortam etkileşimleriyle ilgili algının yüksek olduğunu göstermektedir. Ölçeğin hesaplanan alfa değerleri sırasıyla; öğrenci-arayüz etkileşimi .76, öğrenci-içerik etkileşimi .76, öğrenci-öğretmen etkileşimi .87, öğrenci-öğrenci etkileşimi .95 , öğrenci-ortam etkileşimi .82 şeklindedir. Ölçeğin tamamı için hesaplanan alfa katsayısı ise .92 'dir. Bu araştırmada ise işlemsel uzaklık ile ilgili güvenirlik değerleri sırasıyla; öğrenci-arayüz etkileşimi .78, öğrenci-içerik etkileşimi .68, öğrenci-öğretmen etkileşimi .79, öğrenci-öğrenci etkileşimi .91, öğrenci-ortam etkileşimi .80 şeklindedir. Ölçeğin tamamı için hesaplanan alfa katsayısı ise .93 'tür.

Araştırmaya katılan öğrencilerin ölçek maddelerine samimiyetle yanıt verdikleri sayıltı olarak kabul edilmiştir.

\section{İşlem}

Araştırmada kullanılan veri toplama araçları olan 'Sosyal Bulunuşluk Ölçeği' ve 'Işslemsel Uzaklık Ölçeği' kullanılarak elde edilen veriler 2018-2019 eğitim öğretim yılının Kasım ayında Sosyal Bilimler Meslek Yüksekokulunda uzaktan eğitimle öğrenim gören birinci sınıf öğrencilerinden sınav öncesinde sınıf ortamında elde edilmiştir.

\section{Verilerin Analizi}

Araştırmada 'sosyal bulunuşluk' ve 'işlemsel uzaklık' ölçeklerinden elde edilen veriler SPSS 20.0 programı kullanılarak analiz edilmiştir. Ölçeklerin güvenirliğini belirlemede Cronbach Alpha katsayısına bakılmıştır. Ölçeklerden elde edilen puanların normal dağılıp dağılmadığı test edilmiştir. Bunu test edebilmek için "Kolmogorov-Smirnov Tek Örneklem Testi (KS)" katsayılarından yararlanılmıştır. KS testi sonucu incelendiğinde; sosyal bulunuşluk toplam puanlarında anlamlı farklılık (SW607=0,72, $p<.05$ ) olduğu için normal dağılmadığı, işlemsel uzaklık toplam puanının ise anlamlı olarak farklılaşmadığı (SW607=0,24, p>.05) için normal dağıldığı tespit edilmiştir. Araştırmada, sosyal bulunuşluk ile ilgili analizlerde iki grup karşılaştırmalarında (Mann Whitney U Testi) ve ikiden fazla grup karşılaş̧ırmalarında (Kruskal Wallis Testi) non parametrik testler kullanılmıştır (Büyüköztürk, 2013). İşlemsel uzaklık ile ilgili analizlerde iki grup karşılaştırmalarında (t testi) ve ikiden fazla grup karşılaştırmalarında (ANOVA) parametrik testler kullanılmıştır. 'Sosyal bulunuşluk' ve 'işlemsel uzaklık' arasındaki ilişki hesaplamalarında da Spearman Brown Sıra Farkları korelasyon katsayısı kullanılmıştır.

\section{Bulgular}

\section{Birinci Alt Probleme ilişkin Bulgular}

'Uzaktan eğitim alan üniversite öğrencilerinin sosyal bulunuşlukları ne düzeydedir?' sorusunun analizinde betimsel istatistikler kullanılmıştır. Elde edilen bulgular Tablo 1'de gösterilmiştir.

Tablo 1. Uzaktan Eğitim Alan Üniversite Öğrencilerinin Sosyal Bulunuşluk Düzeylerine illişkin Dağılımları

\begin{tabular}{lllllll}
\hline Ölçekler & $\mathbf{N}$ & $\overline{\boldsymbol{X}}$ & $\mathbf{S}$ & Minimum & Maksimum & Aralık \\
\hline Sosyal Bulunuşluk Ölçeği & 607 & 62,79 & 15,46 & 19,00 & 95,00 & Orta \\
\hline
\end{tabular}


Uzaktan eğitim alan üniversite öğrencilerinin sosyal bulunuşluk düzeyleri $(X=62,79, S=15,46)$ orta düzeydedir.

İkinci Alt Probleme ilişskin Bulgular

Bu alt problemde uzaktan eğitim alan üniversite öğrencilerinin sosyal bulunuşlukları çeşitli değişkenlere göre farklılaşıp farklılaşmadığına ilişkin bulgular yer almaktadır:

\section{Uzaktan eğitim alan üniversite öğrencilerinin cinsiyetlerine ilişkin sosyal bulunuşluk düzeyleri}

'Uzaktan eğitim alan üniversite öğrencilerinin sosyal bulunuşlukları cinsiyete göre farklılaşmakta mıdır? sorusunun analizinde Mann Whitney U Testi yapılmıştır. Sonuçlara ilişkin bulgular Tablo 2.de gösterilmiştir.

Tablo 2. Uzaktan Eğitim Alan Üniversite Öğrencilerinin Cinsiyet Değişkenine Göre Sosyal Bulunuşluk Düzeylerine illişkin Mann Whitney U Testi Sonuçları

\begin{tabular}{lllllll}
\hline Değişkenler & Cinsiyet & N & $\begin{array}{l}\text { Sıra } \\
\text { Ortalaması }\end{array}$ & Sıra Toplamı & U & p \\
\hline Sosyal Bulunuşluk & Kadın & 273 & 295,26 & 80606,00 & 43205,00 & .267 \\
& Erkek & 334 & 311,14 & 103922,00 & & \\
\hline
\end{tabular}

Uzaktan eğitim alan üniversite öğrencilerinin sosyal bulunuşlukları cinsiyete göre farklılaşmamaktadır. ( U=432, p >.05). Sıra ortalamaları dikkate alındığında erkek öğrencilerin sosyal bulunuşluklarının kadınlara göre daha yüksek olduğu anlaşılmaktadır. Ancak bu fark istatistiksel olarak anlamlı değildir.

\section{Uzaktan eğitim alan üniversite öğrencilerinin öğrenim gördükleri bölüme ilişkin sosyal bulunuşluk düzeyleri}

'Uzaktan eğitim alan üniversite öğrencilerinin sosyal bulunuşlukları öğrenim gördükleri bölüme göre farklılaşmakta mıdır? sorusunun analizinde Kruskal Wallis Testi yapılmıştır. Sonuçlara ilişkin bulgular Tablo 3'de gösterilmiştir.

Tablo 3. Uzaktan Eğitim Alan Üniversite Öğrencilerinin Öğrenim Gördükleri Bölüm Değişkenine Göre Sosyal Bulunuşluk Düzeylerine illişkin Kruskal Wallis Testi Testi Sonuçları

\begin{tabular}{llllll}
\hline Bölüm & N & Sıra Ortalaması & sd & X2 & p \\
\hline Büro yönetimi & 96 & 349,54 & 8 & 26,982 & .001 \\
Dış ticaret & 110 & 307,95 & & & \\
İsletme & 30 & 300,02 & & & \\
Lojistik & 43 & 346,66 & & \\
Muhasebe ve Vergi & 82 & 273,62 & & \\
Pazarlama & 43 & 305,63 & & \\
Sosyal Hizmetler & 91 & 317,87 & & \\
Turizm otel & 23 & 339,20 & & \\
Turizm seyahat & 89 & 234,66 & & \\
\hline
\end{tabular}

Uzaktan eğitim alan üniversite öğrencilerinin sosyal bulunuşlukları öğrenim gördükleri bölüme göre farklılaşmaktadır $(p<.05)$. Farklılıkların kaynağı incelendiğinde Turizm seyahat ile lojistik arasında lojistik lehine (KW:26,982 , ( $p<.05)$; Turizm seyahat ile Büro Yönetimi arasında Büro yönetimi lehine anlamlı farklılık bulunmuştur (KW:26,982 , ( $p<.05)$. Grupların sıra ortalamaları dikkate alındığında en yüksek sosyal bulunuşluğa Büro yönetiminde okuyan, en düşük sosyal bulunuşluğa ise Turizm seyahat bölümünde okuyan öğrenciler sahiptir.

\section{Uzaktan eğitim alan üniversite öğrencilerinin öğrenim türüne ilişkin sosyal bulunuşluk düzeyleri}

'Uzaktan eğitim alan üniversite öğrencilerinin sosyal bulunuşlukları öğrenim türüne göre farklılaşmakta mıdır? sorusunun analizinde Mann Whitney U Testi yapılmıştır. Sonuçlara ilişkin bulgular Tablo 4.te gösterilmiştir. 
Tablo 4. Uzaktan Eğitim Alan Üniversite Öğrencilerinin Öğrenim Türü Değişkenine Göre Sosyal Bulunuşluk Düzeylerine İlişkin Mann Whitney U Testi Sonuçları

\begin{tabular}{lllllll}
\hline Değişkenler & Öğrenim Türü & N & Sıra Ortalaması & Sıra Toplamı & U & p \\
\hline Sosyal & Birinci öğretim & 263 & 297,84 & 78333,00 & 43617,00 & .449 \\
Bulunuşluk & İkinci Öğretim & 344 & 308,71 & 106195,00 & & \\
\hline
\end{tabular}

Uzaktan eğitim alan üniversite öğrencilerinin sosyal bulunuşlukları öğrenim türüne göre farklılaşmamaktadır $(U=436, p>.05)$. Sıra ortalamaları dikkate alındığında ikinci öğretim öğrencilerinin sosyal bulunuşluklarının daha yüksek olduğu anlaşılmaktadır. Bu farklılık istatistiksel olarak anlamlı değildir.

\section{Uzaktan eğitim alan üniversite öğrencilerinin öncesinden uzaktan eğitim deneyimine ilişkin sosyal bulunuşluk düzeyleri}

'Uzaktan eğitim alan üniversite öğrencilerinin sosyal bulunuşlukları öncesinden uzaktan eğitim deneyimine göre farklılaşmakta mıdır? sorusunun analizinde Mann Whitney U Testi yapılmıştır. Sonuçlara ilişkin bulgular Tablo 5.te gösterilmiştir.

Tablo 5. Uzaktan Eğitim Alan Üniversite Öğrencilerinin Öncesinden Uzaktan Eğitim Deneyimi Değişkenine Göre Sosyal Bulunuşluk Düzeylerine İlişkin Mann Whitney U Testi Sonuçları

\begin{tabular}{lllllll}
\hline Değişkenler & Uzaktan Eğitim Deneyimi & $\mathbf{N}$ & Sıra Ortalaması & Sıra Toplamı & U & p \\
\hline Sosyal & Var & 58 & 316,97 & 18384,50 & 15168,50 & .553 \\
Bulunuşluk & Yok & 549 & 302,63 & 166143,50 & & \\
\hline
\end{tabular}

Uzaktan eğitim alan üniversite öğrencilerinin sosyal bulunuşlukları uzaktan eğitim deneyimine göre farklılaşmamaktadır ( $U=151, p>.05$ ). Sıra ortalamaları dikkate alındığında daha öncesinden uzaktan eğitim deneyimi olan öğrencilerin sosyal bulunuşlukları, uzaktan eğitim deneyimi olmayan öğrencilerden daha yüksektir. Bu farklılık istatistiksel olarak anlamlı değildir.

Uzaktan eğitim alan üniversite öğrencilerinin teknolojik yeterlilik düzeylerine ilişkin sosyal bulunuşluk düzeyleri

'Uzaktan eğitim alan üniversite öğrencilerinin sosyal bulunuşlukları teknolojik yeterlilik düzeylerine göre farklılaşmakta mıdır? sorusunun analizinde Kruskal Wallis Testi yapılmıştır. Sonuçlara ilişkin bulgular Tablo 6.da gösterilmiştir.

Tablo 6. Uzaktan Eğitim Alan Üniversite Öğrencilerinin Teknolojik Yeterlilik Düzeyi Değişkenine Göre Sosyal Bulunuşluk Düzeylerine iliş̧kin Kruskal Wallis Testi Testi Sonuçları

\begin{tabular}{llllll}
\hline Teknolojik Yeterlilik Düzeyi & $\mathbf{N}$ & Sıra Ortalaması & sd & X2 & p \\
\hline Çok iyi & 66 & 385,40 & 4 & 25,307 & .000 \\
İyi & 175 & 324,43 & & & \\
Orta & 206 & 289,71 & & & \\
Kötü & 93 & 267,21 & & & \\
Çok kötü & 67 & 265,45 & & & \\
\hline
\end{tabular}

Uzaktan eğitim alan üniversite öğrencilerinin sosyal bulunuşlukları teknolojik yeterlilik düzeyine göre farklılaşmaktadır ( $p<.05)$. Farklılıkların kaynağı incelendiğinde çok kötü ile çok iyi arasında çok iyi lehine (KW:25,307 , $(p<.05)$; kötü ile çok iyi arasında çok iyi lehine (KW:25,307, ( $p<.05)$; orta ile çok iyi arasında yine çok iyi lehine $(\mathrm{KW}: 25,307,(\mathrm{p}<.05)$ anlamlı farklılık bulunmuştur. Grupların sıra ortalamaları dikkate alındığında en yüksek sosyal bulunuşluğa teknolojik yeterliliğine çok iyi diyen öğrencilerin, en düşük sosyal bulunuşluğa ise teknolojik yeterliliğine çok kötü yanıtını veren öğrencilerin olduğu anlaşımaktadır.

\section{Uzaktan eğitim alan üniversite öğrencilerinin çalışma durumuna ilişkin sosyal bulunuşluk düzeyleri}

'Uzaktan eğitim alan üniversite öğrencilerinin sosyal bulunuşlukları çalışma durumuna göre farklılaşmakta mıdır? sorusunun analizinde Mann Whitney U Testi yapılmıştır. Sonuçlara ilişkin bulgular Tablo 7.de gösterilmiştir. 
Tablo 7. Uzaktan Eğitim Alan Üniversite Öğrencilerinin Çalışma Durumu Değişkenine Göre Sosyal Bulunuşluk Düzeylerine İlişkin Mann Whitney U Testi Sonuçları

\begin{tabular}{lllllll}
\hline Değişkenler & Çalışma Durumu & $\mathbf{N}$ & Sıra Ortalaması & Sıra Toplamı & U & p \\
\hline Sosyal & Çalışıyorum & 192 & 315,16 & 60511,00 & 37697,00 & .286 \\
Bulunuşluk & Çalışmıyorum & 415 & 298,84 & 124017,00 & & \\
\hline
\end{tabular}

Uzaktan eğitim alan üniversite öğrencilerinin sosyal bulunuşlukları çalışma durumuna göre farklılaşmamaktadır $(\mathrm{U}=37697, \mathrm{p}>.05)$. Sıra ortalamaları dikkate alındığında çalışan öğrencilerin sosyal bulunuşlukları çalışmayan öğrencilerden daha yüksektir. Bu farklılık istatistiksel olarak anlamlı değildir.

\section{Uzaktan eğitim alan üniversite öğrencilerinin üniversite öncesi yaşadığı yere ilişkin sosyal bulunuşluk düzeyleri}

'Uzaktan eğitim alan üniversite öğrencilerinin sosyal bulunuşlukları üniversite öncesi yaşadığı yere göre farklılaşmakta mıdır? sorusunun analizinde Kruskal Wallis Testi yapılmıştır. Sonuçlara ilişkin bulgular Tablo 8.de gösterilmiştir.

Tablo 8. Uzaktan Eğitim Alan Üniversite Öğrencilerinin Üniversite Öncesi Yaşadığı Yer Değişkenine Göre Sosyal Bulunuşluk Düzeylerine İlişkin Kruskal Wallis Testi Testi Sonuçları

\begin{tabular}{llllll}
\hline Üniversite Öncesi yaşadığı yer & $\mathbf{N}$ & Sıra Ortalaması & sd & X2 & p \\
\hline büyükşehir(merkez) & 287 & 297,75 & 3 & 1,328 & .722 \\
il(kent)merkezi & 97 & 307,95 & & & \\
ilçe merkezi & 158 & 304,37 & & & \\
belde veya köy & 65 & 324,78 & & & \\
\hline
\end{tabular}

Uzaktan eğitim alan üniversite öğrencilerinin sosyal bulunuşlukları üniversite öncesi yaşadığı yere göre farklılaşmamaktadır ( $p>05$ ). Grupların sıra ortalamaları dikkate alındığında en yüksek sosyal bulunuşluğa belde veya köyde yaşayan öğrencilerin en düşük sosyal bulunuşluğa ise büyükşehirde yaşayan öğrencilerin sahip olduğu anlaşılmaktadır. Bu farklılık istatistiksel olarak anlamlı değildir.

\section{Üçüncü Alt Probleme i̇lişkin Bulgular}

'Uzaktan eğitim alan üniversite öğrencilerinin işlemsel uzaklıkları ne düzeydedir?' sorusunun analizinde betimsel istatistikler kullanılmıştır. Sonuçlara ilişkin bulgular Tablo 9.da gösterilmiştir.

Tablo 9. Uzaktan Eğitim Alan Üniversite Öğrencilerinin İşlemsel Uzaklık Düzeylerine ilişkin Dağılımları

\begin{tabular}{llcllll}
\hline Ölçekler & $\mathbf{N}$ & $\overline{\boldsymbol{X}}$ & $\mathbf{S}$ & Minimum & Maksimum & Aralık \\
\hline $\begin{array}{l}\text { Işslemsel } \\
\text { Uzaklık Ölçeği }\end{array}$ & 607 & 117,529 & 25,396 & 44,00 & 183,00 & Orta \\
\hline
\end{tabular}

Uzaktan eğitim alan üniversite öğrencilerinin işlemsel uzaklık düzeyleri $(X=117,529$, S=25,396) orta düzeydedir.

\section{Dördüncü Alt Probleme ilişkin Bulgular}

Bu alt problemde uzaktan eğitim alan üniversite öğrencilerinin işlemsel uzaklıkları çeşitli değişkenlere göre farklılaşıp farklılaşmadığına ilişkin bulgular yer almaktadır:

\section{Uzaktan eğitim alan üniversite öğrencilerinin cinsiyetlerine ilişkin işlemsel uzaklık düzeyleri}

'Uzaktan eğitim alan üniversite öğrencilerinin işlemsel uzaklıkları cinsiyete göre farklılaşmakta mıdır? sorusunun analizinde t testi yapılmıştır. Sonuçlara ilişkin bulgular Tablo 10.da gösterilmiştir.

Tablo 10. Uzaktan Eğitim Alan Üniversite Öğrencilerinin Cinsiyet Değişkenine Göre İşlemsel Uzaklık Düzeylerine iliş̧kin t Testi Sonuçları 


\begin{tabular}{llllllll}
\hline Değişkenler & Cinsiyet & $\mathbf{N}$ & $\overline{\boldsymbol{X}}$ & $\mathbf{S}$ & $\mathbf{s d}$ & $\mathbf{t}$ & $\mathbf{p}$ \\
\hline İşlemsel Uzaklık & Kadın & 273 & 116,0513 & 23,96100 & 605 & 1,297 & .195 \\
& Erkek & 334 & 118,7368 & 26,48659 & & & \\
\hline
\end{tabular}

Uzaktan eğitim alan üniversite öğrencilerinin işlemsel uzaklıkları cinsiyete göre farklılaşmamaktadır(t $(605)=1,297$, p> .05). Erkek öğrencilerin işlemsel uzaklıkları kadınlara göre daha yüksektir.

\section{Uzaktan eğitim alan üniversite öğrencilerinin öğrenim gördükleri bölüme ilişkin işlemsel uzaklık düzeyleri}

'Uzaktan eğitim alan üniversite öğrencilerinin işlemsel uzaklıkları öğrenim gördükleri bölüme göre farklılaşmakta mıdır? sorusunun analizinde ANOVA yapılmıştır. Sonuçlara ilişkin bulgular Tablo 11.de gösterilmiştir.

Tablo 11. Uzaktan Eğitim Alan Üniversite Öğrencilerinin Öğrenim Gördükleri Bölüm Değişkenine Göre İşlemsel Uzaklık Düzeylerine ìlişkin ANOVA Sonuçları

\begin{tabular}{lllll}
\hline Bölüm & $\mathrm{N}$ & & $\overline{\boldsymbol{X}}$ & $\mathrm{S}$ \\
\hline Büro yönetimi & 96 & 126,739 & 23,878 \\
Dış ticaret & 110 & 120,609 & 28,982 \\
Işletme & 30 & 123,766 & 18,973 \\
Lojistik & 43 & 119,279 & 24,471 \\
$\begin{array}{l}\text { Muhasebe ve } \\
\text { Vergi }\end{array}$ & 82 & 115,353 & 22,209 \\
$\begin{array}{l}\text { Pazarlama } \\
\text { Sosyal }\end{array}$ & 43 & 116,372 & \\
Hizmetler & 91 & 116,417 & 26,859 \\
$\begin{array}{l}\text { Turizm otel } \\
\text { Turizm }\end{array}$ & 23 & 115,434 & 24,602 \\
$\begin{array}{l}\text { seyahat } \\
\text { Toplam }\end{array}$ & 89 & 105,078 & 28,240 \\
& & & 21,931 \\
\end{tabular}

\begin{tabular}{llllll}
\hline Varyansın kaynağı & Kareler toplamı & Sd & Kareler ortalaması & F & P \\
\hline Gruplar arası & 24942,052 & 8 & 3117,756 & & \\
Grup içi & 365917,222 & 598 & 611,902 & 5,095 &, 000 \\
Toplam & 390859,274 & 606 & & & \\
\hline
\end{tabular}

Uzaktan eğitim alan üniversite öğrencilerinin işlemsel uzaklıkları öğrenim gördükleri bölüme göre farklılaşmaktadır (F8-598=5,095, $\mathrm{p}<\mathrm{.01}$ ). Post-Hoc testlerinden Dunnett C yapılarak farklılıkların kaynakları incelendiğinde; Büro yönetimi ile muhasebe-vergi arasında ve büro yönetimi ile turizm-seyahat atasında büro yönetimi lehine, dış ticaret ile turizm-seyahat arasında dış ticaret lehine, işletme ile turizm-seyahat arasında işletme lehine, sosyal hizmetler ile turizm-seyahat arasında sosyal hizmetler lehine anlamlı farklılık bulunmuştur $(p<.01)$.

\section{Uzaktan eğitim alan üniversite öğrencilerinin öğrenim türüne ilişkin işlemsel uzaklık düzeyleri}

'Uzaktan eğitim alan üniversite öğrencilerinin işlemsel uzaklıkları öğrenim türüne göre farklılaşmakta mıdır? sorusunun analizinde $t$ testi yapılmıştır. Sonuçlara ilişkin bulgular Tablo 12.de gösterilmiştir.

Tablo 12. Uzaktan Eğitim Alan Üniversite Öğrencilerinin Öğrenim Türü Değişkenine Göre İşlemsel Uzaklık Düzeylerine İlişkin t Testi Sonuçları

\begin{tabular}{llllllll}
\hline Değişkenler & Öğrenim Türü & $\mathbf{N}$ & $\overline{\boldsymbol{X}}$ & $\mathbf{S}$ & $\mathbf{s d}$ & $\mathbf{t}$ & $\mathbf{P}$ \\
\hline Işlemsel Uzaklık & Birinci öğretim & 263 & 118,327 & 25,36692 & 605 & .677 & .499 \\
& ikinci öğretim & 344 & 116,918 & 25,43911 & & & \\
\hline
\end{tabular}

Uzaktan eğitim alan üniversite öğrencilerinin işlemsel uzaklıkları öğrenim türüne göre farklılaşmamaktadır $(\mathrm{t}$ (605): .677, p> .05). Birinci öğretime devam eden öğrencilerin işlemsel uzaklıkları ikinci öğretime devam eden öğrencilerden daha yüksektir. Bu farklıık istatistiksel olarak anlamlı değildir. 
Uzaktan eğitim alan üniversite öğrencilerinin öncesinden uzaktan eğitim deneyimine ilişkin işlemsel uzaklık düzeyleri

'Uzaktan eğitim alan üniversite öğrencilerinin işlemsel uzaklıkları öncesinden uzaktan eğitim deneyimine göre farklılaşmakta mıdır? sorusunun analizinde $t$ testi yapılmıştır. Sonuçlara ilişkin bulgular Tablo 13.te gösterilmiştir.

Tablo 13. Uzaktan Eğitim Alan Üniversite Öğrencilerinin Öncesinden Uzaktan Eğitim Deneyimi Değişkenine Göre İşlemsel Uzaklık Düzeylerine İlişkin t Testi Sonuçları

\begin{tabular}{llllllll}
\hline Değişkenler & Uzaktan Eğitim Deneyimi & $\mathbf{N}$ & $\overline{\boldsymbol{X}}$ & $\mathbf{S}$ & $\mathbf{s d}$ & $\mathbf{t}$ & $\mathbf{p}$ \\
\hline İşlemsel Uzaklık & Var & 58 & 122,189 & 28,41451 & 605 & 1,471 & .142 \\
& Yok & 549 & 117,036 & 25,03448 & & & \\
\hline
\end{tabular}

Uzaktan eğitim alan üniversite öğrencilerinin işlemsel uzaklıkları uzaktan eğitim deneyimine göre farklılaşmamaktadır (t (605): 1,471, p> .05). Öncesinden uzaktan eğitim deneyimi olan öğrencilerin işlemsel uzaklıkları uzaktan eğitim deneyimi olmayanlara göre daha yüksektir. Bu farklılık istatistiksel olarak anlamlı değildir.

Uzaktan eğitim alan üniversite öğrencilerinin teknolojik yeterlilik düzeylerine ilişkin işlemsel uzaklık düzeyleri

'Uzaktan eğitim alan üniversite öğrencilerinin işlemsel uzaklıkları teknolojik yeterlilik düzeylerine göre farklılaşmakta mıdır? sorusunun analizinde ANOVA yapılmıştır. Sonuçlara ilişkin bulgular Tablo 14.te gösterilmiştir.

Tablo 14. Uzaktan Eğitim Alan Üniversite Öğrencilerinin Teknolojik Yeterlilik Düzeyi Değişkenine Göre İşlemsel Uzaklık Düzeylerine İlişkin ANOVA Sonuçları

\begin{tabular}{|c|c|c|c|c|c|c|}
\hline \multicolumn{2}{|c|}{ Teknolojik yeterlilik düzeyi } & \multicolumn{2}{|l|}{$\mathbf{N}$} & $\bar{X}$ & \multicolumn{2}{|l|}{$\mathbf{S}$} \\
\hline Çok iyi & & \multicolumn{2}{|c|}{66} & 129,7273 & \multicolumn{2}{|c|}{26,857} \\
\hline İyi & & \multicolumn{2}{|c|}{175} & 126,1657 & \multicolumn{2}{|c|}{23,355} \\
\hline Orta & & \multicolumn{2}{|c|}{206} & 117,8641 & \multicolumn{2}{|c|}{21,994} \\
\hline Kötü & & \multicolumn{2}{|c|}{93} & 104,9149 & \multicolumn{2}{|c|}{21,487} \\
\hline Çok kötü & & \multicolumn{2}{|c|}{67} & 99,4328 & \multicolumn{2}{|c|}{26,904} \\
\hline Toplam & & \multicolumn{2}{|c|}{607} & 117,5290 & \multicolumn{2}{|c|}{25,396} \\
\hline $\begin{array}{l}\text { Varyansın } \\
\text { kaynağı }\end{array}$ & Kareler & & Sd & $\begin{array}{l}\text { Kareler } \\
\text { ortalaması }\end{array}$ & $\mathbf{F}$ & $\mathbf{p}$ \\
\hline Gruplar arası & 59635,8 & & 4 & 14908,960 & & \\
\hline Grup içi & 331223 & & 602 & 550,205 & 27,097 & ,000 \\
\hline Toplam & 390859 & & 606 & & & \\
\hline
\end{tabular}

Uzaktan eğitim alan üniversite öğrencilerinin işlemsel uzaklıkları teknolojik yeterlilik düzeylerine göre farklılaşmaktadır (F4-602=27,097, $\mathrm{p}<$.01). Post-Hoc testlerinden Scheffe yapılarak farklılıkların kaynakları incelendiğinde; çok iyi ile orta, kötü, çok kötü arasında çok iyi lehine, iyi ile orta, kötü, çok kötü arasında iyi lehine, orta ile kötü, çok kötü arasında orta lehine anlamlı farklılık bulunmuştur $(p<.01)$.

\section{Uzaktan eğitim alan üniversite öğrencilerinin çalışma durumuna ilişkin işlemsel uzaklık düzeyleri}

'Uzaktan eğitim alan üniversite öğrencilerinin işlemsel uzaklıkları çalışma durumuna göre farklılaşmakta mıdır? sorusunun analizinde $t$ testi yapılmıştır. Sonuçlara ilişkin bulgular Tablo 15.te gösterilmiştir.

Tablo 15. Uzaktan Eğitim Alan Üniversite Öğrencilerinin Çalışma Durumu Değişkenine Göre iş̧lemsel Uzaklık Düzeylerine İlişkin $t$ Testi Sonuçları

\begin{tabular}{|c|c|c|c|c|c|c|c|}
\hline Değişkenler & $\begin{array}{l}\text { Çalışma } \\
\text { durumu }\end{array}$ & $\mathbf{N}$ & $\overline{\boldsymbol{X}}$ & $\mathbf{S}$ & sd & $\mathbf{t}$ & p \\
\hline \multirow[t]{2}{*}{ İşlemsel Uzaklık } & Çalışıyorum & 192 & 117,969 & 26,69135 & 605 & .290 & .772 \\
\hline & Calıșmıyorum & 415 & 117,325 & 24,80509 & & & \\
\hline
\end{tabular}

Uzaktan eğitim alan üniversite öğrencilerinin işlemsel uzaklıkları çalışma durumuna göre farklılaşmamaktadır ( $t$ (605): .290, p>.05). 
Uzaktan eğitim alan üniversite öğrencilerinin üniversite öncesi yaşadığı yere ilişkin işlemsel uzaklık düzeyleri

'Uzaktan eğitim alan üniversite öğrencilerinin işlemsel uzaklıkları üniversite öncesi yaşadığı yere göre farklılaşmakta mıdır? sorusunun analizinde ANOVA yapılmıştır. Sonuçlara ilişkin bulgular Tablo 16.da gösterilmiştir.

Tablo 16. Uzaktan Eğitim Alan Üniversite Öğrencilerinin Üniversite Öncesi Yaşadığı Yer Değişkenine Göre İşlemsel Uzaklık Düzeylerine İlişkin ANOVA Sonuçları

\begin{tabular}{llll}
\hline Üniversite öncesi yaşadığı yer & $\mathrm{N}$ & \multicolumn{1}{c}{$\overline{\mathrm{X}}$} & $\mathrm{S}$ \\
\hline Büyükşehir(merkez) & 287 & 115,8258 & 25,865 \\
il(kent)merkezi & 97 & 118,5163 & 26,105 \\
ilç̧e merkezi & 158 & 119,1646 & 24,374 \\
Belde veya köy & 65 & 119,6000 & 24747 \\
Toplam & 607 & 117,5290 & 25,396 \\
\hline
\end{tabular}

\begin{tabular}{|c|c|c|c|c|c|c|}
\hline Varyansın kaynağı & Kareler toplamı & $\mathrm{Sd}$ & & Kareler ortalaması & $\mathrm{F}$ & $P$ \\
\hline Gruplar arası & 1628,577 & 3 & & 542,859 & & \\
\hline Grup içi & 389230,697 & & 603 & 645,490 & .841 & .472 \\
\hline Toplam & 390859,274 & & 606 & & & \\
\hline
\end{tabular}

Uzaktan eğitim alan üniversite öğrencilerinin işlemsel uzaklıkları üniversite öncesi yaşadıkları yere göre farklılaşmamaktadır (F3-603=,841 p> .05).

\subsection{Beşinci Alt Probleme iliş̧kin Bulgular}

Uzaktan eğitim alan üniversite öğrencilerinin sosyal bulunuşluk düzeyleri ile işlemsel uzaklıkları arasındaki ilişki ne düzeydedir? Sorusunun analizinde sosyal bulunuşluk normal dağılmadığından Spearman Brown sıra farkları korelasyonu yapılmıştır. Sonuçlara ilişkin bulgular Tablo 17.de gösterilmiştir.

Tablo 17. Uzaktan Eğitim Alan Üniversite Öğrencilerinin Sosyal Bulunuşluk i̇e İşlemsel Uzaklık Düzeyleri Ve Alt Boyutları Arasındaki İlişkiyi Gösteren Spearman Brown Sıra Farkları Korelasyonu Sonuçları

\begin{tabular}{lllllllllll}
\hline Değişkenler & 1 & 2 & 3 & 4 & 5 & 6 & 7 & 8 & 9 & 10 \\
\hline 1. Ortak Bulunuşluk & 1 & & & & & & & & \\
2. Etkileme & $.668^{*}$ & 1 & & & & & & & \\
3. Kaynaştırma & $.634^{*}$ & $.815^{*}$ & 1 & & & & & & \\
4. Top. Sosyal Bulunuşluk & $.806^{*}$ & $.932^{*}$ & $.930^{*}$ & 1 & & & & & & \\
5.Öğrenci-arayüz etkileşimi & $.208^{*}$ & $.215^{*}$ & $.218^{*}$ & $.236^{*}$ & 1 & & & & \\
6. Öğrenci içerik etkileşimi & $.341^{*}$ & $.375^{*}$ & $.397^{*}$ & $.411^{*}$ & $.736^{*}$ & 1 & & & \\
7.Öğrenci öğretmen etkileşim & $.240^{*}$ & $.321^{*}$ & $.300^{*}$ & $.321^{*}$ & $.709^{*}$ & $.504^{*}$ & 1 & & \\
8. Öğrenci öğrenci etkileşimi & $.408^{*}$ & $.425^{*}$ & $.432^{*}$ & $.462^{*}$ & $.882^{*}$ & $.634^{*}$ & $.561^{*}$ & 1 & \\
9. Öğrenci-ortam etkileşimi & $.416^{*}$ & $.445^{*}$ & $.448^{*}$ & $.478^{*}$ & $.833^{*}$ & $.593^{*}$ & $.514^{*}$ & $.670^{*}$ & 1 \\
10. Top. işlemsel uzaklık & $490^{*}$ & $.574^{*}$ & $.558^{*}$ & $.600^{*}$ & $.684^{*}$ & $.736^{*}$ & $.709^{*}$ & $.833^{*}$ & $.841^{*}$ & 1 \\
\hline
\end{tabular}

Sosyal bulunuşlukta boyutlar arasındaki en yüksek ilişki, etkileme ve kaynaştırma arasında ( $r=.815)$, en düşük ilişki ise ortak bulunuşluk ile kaynaştırma $(r=.634)$ arasındadır. İşlemsel uzaklıkta boyutlar arasındaki ilişkiler incelendiğinde en yüksek ilişkinin öğrenci-arayüz etkileşimi ile öğrenci-öğrenci etkileşimi arasında $(r=.882)$ olduğu 
görülmektedir.

Uzaktan eğitim alan üniversite öğrencilerinin ölçeklerin geneline göre sosyal bulunuşluk ile işlemsel uzaklık düzeyleri arasındaki ilişkiler incelendiğinde iki değişken arasında pozitif yönde orta düzeyin üzerinde ve anlamlı bir ilişki olduğu görülmektedir ( $r=.600, p<.05)$. Buna göre sosyal bulunuşluk arttıkça işlemsel uzaklığın da arttığı söylenebilir.

\section{Tartışma, Sonuç ve Öneriler}

Araştırmanın sonuçlarına bakıldığında uzaktan eğitim alan üniversite öğrencilerinin sosyal bulunuşluklarının orta düzeyde olduğu tespit edilmiştir. Tu ve Mclsaac (2002) ile Aragon (2003) yaptıkları çalışmalarda çevrimiçi öğrenme ortamlarında öğrencilerin sosyal bulunuşluklarını arttırmak için aşırı eleştiriden kaçınmak, öğrencileri desteklemek, takdir etmek ve yapıcı mesajlar paylaşmanın önemli olduğunu belirtmişlerdir. Tüzün vd. (2016) de yaptıkları çalışmada öğrencilerin sosyal buradalık düzeylerinin orta düzeyin üzerinde olduğu sonucuna ulaşmıştır. Öğrencilerin sosyal bulunuşlukları cinsiyete, öğrenim türüne, öncesinden uzaktan eğitim deneyimine, çalışma durumuna ve üniversite öncesi yaşadığı yere göre farklılaşmamaktadır. Kip (2007), Garrison, Cleveland-Innes, ve Fung (2010) ve Tüzün vd. (2016) de yaptıkları çalışmalarda cinsiyetin sosyal bulunuşluk üzerinde herhangi bir farklılaşma oluşturmadığını tespit etmiştir. Öğrenim gördükleri bölüme ve teknolojik yeterlilik düzeylerine göre ise öğrencilerin sosyal bulunuşlukları farklılaşmaktadır. Farklııkların kaynağı incelendiğinde; turizm seyahat ile lojistik arasında lojistik lehine, turizm seyahat ile büro yönetimi arasında büro yönetimi lehine anlamlı farklılık bulunmuştur. Grupların sıra ortalamaları dikkate alındığında en yüksek sosyal bulunuşluğa büro yönetiminde okuyan, en düşük sosyal bulunuşluğa ise turizm seyahat bölümünde okuyan öğrenciler sahiptir. Küresel ölçekte düşünüldüğünde iletişim, ulaşım ve teknolojik anlamda sınırların ortadan kalktığı bir dünyada yaşanılmaktadır. Bu değişim ve gelişmeyi takip edip bunun sürdürücüsü konumunda olan mesleklerin başında ise turizm işiyle uğraşanların gelmesine rağmen teknolojik sistemin ve sosyal ilişkinin merkezinde yer alan turizm seyahat öğrencilerinin uzaktan eğitim sisteminde sosyal bulunuşluklarının düşük çıkması şaşırtıcı gelmiş olabilir. Teknolojik yeterlilik anlamında ise çok kötü ile çok iyi, kötü ile çok iyi ve orta ile çok iyi arasında çok iyi lehine anlamlı farklııık bulunmuştur. Grupların sıra ortalamaları dikkate alındığında en yüksek sosyal bulunuşluğa teknolojik yeterliliğine çok iyi diyen öğrencilerin, en düşük sosyal bulunuşluğa ise çok kötü yanıtını veren öğrencilerin sahip olduğu anlaşılmaktadır. Uzaktan eğitim sisteminin hem öğreticilik hem de sosyalleşme anlamında başarılı olmasının ana faktörlerinden birisini teknolojik yeterlilik ile becerinin oluşturduğu göz önünde bulundurulursa bu bulgunun beklenilen bir sonuç olduğu söylenebilir. Sosyal bulunuşluk ile ilgili çalışmada dikkat çeken unsurlardan biri de öğrencilerin üniversite öncesi yaşadığı yer değişkeninde grupların sıra ortalamaları dikkate alındığında en yüksek sosyal bulunuşluğa belde veya köyde yaşayan öğrencilerin en düşük sosyal bulunuşluğa ise büyükşehirde yaşayan öğrencilerin sahip olduğu anlaşılmaktadır. Bu durum; öğrencilerin belde veya köy ortamında teknolojik imkanların yetersizliği, insan sayısının azlı̆ından kaynaklı sosyalleşme imkanının sınırlı olmasından dolayı öğrencilerde uzaktan eğitim sistemine ayrı bir merak, istek, öğrenme azmi ve -uzaktan eğitim ortamı da olsa- diğer bireylerle sosyal ilişki kurma isteğiyle açıklanabilir.

Uzaktan eğitim alan üniversite öğrencilerinin işlemsel uzaklıklarının orta düzeyde olduğu tespit edilmiştir. Çevrimiçi öğrenme ortamlarında işlemsel uzaklık algılarının azaltılması için Bayır (2014) öğrencilerin hem sohbet etmelerinin hem de e-posta yoluyla mesajlaşmalarının önemli olduğu sonucuna ulaşmıştır. Barrett (2002) haber bültenleri, sohbet araçları, öğrencilere sorular sorulması ve etkili bir tartışma ortamının oluşması gerektiğini belirtmiştir. Aluko, Hendrikz ve Fraser (2011) ise ders tanıtımının yapılmasının, nitelikli ve amaca hizmet eden materyallerin hazırlanmasının, uygulanabilir içeriğin ve öğrencilere danışmanlık hizmeti verilmesinin gerekli olduğunu belirtmiştir. İşlemsel uzaklıkla ilgili çıkan sonuçların sosyal bulunuşluk ile ilgili sonuçlarla benzer nitelik taşıdığı gözlenmektedir. Hem sosyal bulunuşluğun hem de işlemsel uzaklığın orta düzeyde çıkması uzaktan eğitim sistemine yöneltilen; öğrencilerin kendilerini yalnız hissetmesi, yeterli etkileşim kuramaması, birbirilerinin çalışmalarını etkileyememesi ve paylaşım ortamı oluşturamaması gibi problemlerin öğrenciler üzerinde pek de fazla etkili olmadığı şeklinde açıklanabilir. Yani uzaktan eğitim sistemiyle öğrenim gören öğrencilerin yaklaşık yarısının bu ortamlarda kendilerini göreceli olarak sosyal hissettiği ve arkadaşlarıyla etkileşime girdikleri söylenebilir. Öğrencilerin işlemsel uzaklıkları cinsiyete, öğrenim türüne, öncesinden uzaktan eğitim deneyimine, çalışma durumuna ve üniversite öncesi yaşadığı yere göre farklılaşmamaktadır. Bayır ve Mahiroğlu (2017) yaptıkları çalışmada cinsiyetin, Özkaya (2013) da hem cinsiyetin hem de uzaktan eğitim deneyiminin işlemsel uzaklık üzerinde herhangi bir farklılaşma oluşturmadığını tespit etmiştir. Hopper (2000) yaptığı çalışmada öğrencilerin işlemsel uzaklık algıları ile cinsiyetleri arasında anlamlı pozitif bir ilişki olduğu sonucuna ulaşmıştır. Öğrencilerin işlemsel uzaklıkları öğrenim gördükleri bölüm ve teknolojik yeterlilik düzeylerine göre ise farklılaşmaktadır. Öğrencilerin okudukları bölümlere göre farklılıklar incelendiğinde; büro yönetimi ile muhasebe-vergi arasında ve büro yönetimi ile turizm-seyahat atasında büro yönetimi lehine, dış 
ticaret ile turizm-seyahat arasında dış ticaret lehine, işletme ile turizm-seyahat arasında işletme lehine, sosyal hizmetler ile turizm-seyahat arasında sosyal hizmetler lehine anlamlı farklılık bulunmuştur. Turizm seyahat öğrencilerinin sosyal bulunuşluk anlamında olduğu gibi işlemsel uzaklık anlamında da olumsuz şekilde farklılaşması iletişim, ulaşım ve teknolojik anlamda sınırların ortadan kalktığı dijital çağda bu değişim ve gelişmeyi takip edip bunun sürdürücüsü konumunda olan mesleklerin başında turizm işiyle uğraşanların gelebileceği varsayıldığından teknolojik sistemin ve sosyal ilişkinin merkezinde yer alan turizm seyahat öğrencilerinin uzaktan eğitim sisteminde işlemsel uzaklıklarının düşük çıkması manidar bulunmuştur. Teknolojik yeterlilikte ise; çok iyi ile orta, kötü, çok kötü arasında çok iyi lehine, iyi ile orta, kötü, çok kötü arasında iyi lehine, orta ile kötü, çok kötü arasında orta lehine anlamlı farklııık bulunmuştur. Bu durum; teknolojik yeterlilik arttıkça öğrencilerin işlemsel uzaklıklarının da düzenli olarak arttığı, çevrimiçi öğrenme ortamında bulunma düzeyi arttıkça bireyin kendini o ortamın bir parçası olarak hissettiği, o ortamdaki diğer bireylerle iletişim halinde ve bir şeyler paylaşma isteği içinde olduğu şeklinde açıklanabilir. Sosyal bulunuşlukta olduğu gibi üniversite öncesinde belde veya köyde yaşayan öğrencilerin işlemsel uzaklıkları daha yüksektir. Bu durumun belde veya köy ortamında teknolojik imkanların yetersizliği, belde ve köylerde nüfusun azlığından kaynaklı sosyalleşme imkanının sınırlı olması belde veya köyde yaşayan öğrencilerin uzaktan eğitim sistemine ayrı bir merak ve -uzaktan eğitim ortamı da olsa- diğer bireylerle sosyal ilişki kurma isteğinden kaynaklandığı söylenebilir.

Sosyal bulunuşluk ile işlemsel uzaklık ölçeklerinin toplam puanları arasındaki ilişkiye bakıldığında pozitif yönde orta düzeyin üzerinde ve anlamlı bir ilişki olduğu tespit edilmiştir. Bu sonuçlara göre sosyal bulunuşluk ile işlemsel uzaklık kavramları birbirleriyle ilişkili kabul edilebilir. iki kavramın birbiri açısından önemli olduğu, birbirini desteklediği ve biri arttığında diğerinin de olumlu yönde arttığı belirtilebilir. Yılmaz (2017) yaptığı uluslararası çalışmasında öğrencilerin sanal ortam öğrenmelerinde sosyal bulunuşluk ve işlemsel uzaklıkların öğrenciler üzerinde etkili olduğunu ve bu kavramların birbiriyle ilişkili olduğunu ortaya koymuştur. Farklı sonuçlara ulaşan araştırmacılar da vardır. Lowell (2004) yaptığı çalışmada çevrimiçi ve eş zamanlı yürütülen ders etkinliği sonrasında işlemsel uzaklık algısı ile öğrencilerin sosyal buradalıkları arasındaki ilişkiyi incelemiş ve öğrencilerin işlemsel uzaklık algıları azaldıkça sosyal buradalıkları artmaktadır. Yani negatif yönde bir ilişki olduğu sonucuna ulaşmıştır. Nwankwo (2013) tarafından yapılan ve işlemsel uzaklık algısının alt boyutları arasındaki ilişkinin incelendiği çalışmada öğrenci-öğrenci, öğrenci-öğretmen ve öğrenci-içerik etkileşiminin işlemsel uzaklık algısı ile anlamlı ilişki bulunmadığı sonucuna varılmıştır. Sonuç olarak uzaktan eğitim alan üniversite öğrencilerinin sosyal bulunuşluk ve işlemsel uzaklıkları orta düzeydedir. Sosyal bulunuşlukları ve işlemsel uzaklıkları; cinsiyete, öğrenim türüne, uzaktan eğitim deneyimine, çalışma durumuna ve üniversite öncesi yaşadığı yere göre farklılaşmamakta, öğrenim gördükleri bölüm ve teknolojik yeterlilik düzeylerine göre ise farklılaşmaktadır. Öğrencilerin sosyal bulunuşluk ile işlemsel uzaklıkları arasındaki ilişkiye bakıldığında pozitif yönde orta düzeyin üzerinde ve anlamlı bir ilişki olduğu sonucuna varılmıştır.

Bu araştırmada Mersin Üniversitesi Sosyal Bilimler Meslek Yüksekokulunda öğrenim gören birinci sınıf öğrencilerinin sosyal bulunuşluk ile işlemsel uzaklıkları ve bunların bazı değişkenlere göre farklılaşıp farklılaşmadıkları nicel araştırma yöntemlerinden ilişkisel tarama modelinde çalışılıştır. Uzaktan eğitim alan öğrencilerin sosyal bulunuşluklarının ve işlemsel uzaklıklarının geliştirilmesi için uzaktan eğitime başlamadan önce öğrencilere oryantasyon eğitimi verilebilir. Uzaktan eğitim süreci devam ederken öğrencilerle yüz yüze görüşmeler yapılarak onlardan uzaktan eğitimle ilgili geri bildirimler alınabilir. Araştırmanın sosyal bulunuşluk ile ilgili bulgusundan hareketle uzaktan eğitim ortamında ileri teknolojik tekniklerden yararlanılarak zenginleştirilmiş ve öğrencilerde sosyal etkileşim ve bulunuşluklarını arttırıcı ortamlar oluşturulabilir. Farklı üniversitelerden ve bölümlerden seçilen öğrenci gruplarıyla karma yöntemle çalışma yapııması daha geniş ve genellenebilir sonuçlar verebilir. Uzaktan eğitim sistemiyle ilgili farklı değişkenler kullanılarak yarı deneysel bir yöntemle çalışma yapılması daha farklı ve olumlu sonuçlar verebilir. Sosyal bulunuşluk ile işlemsel uzaklık kavramlarının nitel yöntemle çalışıması alan yazına farklı, ayrıntılı ve faydalı bilgiler sunabilir.

\section{Kaynakça}

Aluko, R. F., Hendrikz, J. \& Fraser, W. J. (2011). Transactional distance theory and total quality management in open and distance learning. Africa Education Review, 8(1), 115-132.

Aragon, S. R. (2003). Creating social presence in online environment. New Directions for Adult and Continuing Education, 100, 57-68.

Barrett, D. J. (2002). Change communication, use strategic employee communication to facilitate major change. corporate communications: An International Journal, 7(4), 219-231. 
Bayır, E. A. (2014). Çevrimiçi öğrenme ortamlarında sohbet ve e-posta kullanımının öğrencilerin işlemsel uzaklık algılarına etkisi. Doktora tezi, Gazi Üniversitesi, Ankara.

Bayır, A, E. \& Mahiroğlu, A. (2017). Çevrimiçi öğrenmede bireysel farklılıklar ve iletişim ortamlarının işlemsel uzaklık algısına etkisi. Ege Eğitim Dergisi, 18 (1), 430-447.

Berge, Z, L. (1995). Facilitating Computer Conferencing: Recommendations from the field. Educational technology, 15(1), 22-30.

Bozkurt, A. (2017). Türkiye'de uzaktan eğitimin dünü, bugünü ve yarını. Açıköğretim Uygulamaları ve Araştırmaları Dergisi, 3 (2), 85-124.

Büyüköztürk, Ş. (2013). Sosyal bilimler için veri analizi el kitabı. Ankara: Pegem Akademi.

Christie, B., Short, J. \& Williams, E. (1976). The social psychology of telecommunications. London: John Wiley ve Sons.

Cohen, L. , Manion, L. \& Morrison, K. (2000). Eğitimde araştırma yöntemleri. Londra: Routledge Falmer.

Edwards, J. T. (2009). Undergraduate students' perceptions and preferences of computermediated communication with faculty. American Communication Journal, 11(1), 1-10.

Elcil, Ş. ve Şahiner, S. D. (2014). Uzaktan eğitimde iletişimsel engeller. Sosyal ve Beşeri Bilimler Dergisi, 6 (1).

Garrison, D. R. (1999). Will distance disappear in distance education? A Reaction. Journal Of Distance Education, 14 (2).

Garrison, D. R., Anderson, T., \& Archer, W. (2000). Critical inquiry in a text-based environment: Computer conferencing in higher education. The Internet and Higher Education, 2(2), 87-105.

Garrison, D.R., Cleveland-Innes, M. \& Fung, T. (2010). Exploring causal relationships among cognitive, social and teaching presence: student perceptions of the community of inquiry framework. The Internet And Higher Education, 13(12), 31-36.

Gökmen, F. Ö., Duman, i. ve Horzum, B. M. (2016). Uzaktan eğitimde kuramlar, değişimler ve yeni yönelimler. Açıöğretim Uygulamaları ve Araştırmaları Dergisi, 2 (3), 29-51.

Gunawardena, C. \& Zittle, F. (1997). Social presence as a predictor of satisfaction within a computer-mediated conferencing environment, American Journal Of Distance Education, 11(3), 8-26.

Hopper, D. A. (2000). Learner characteristics, life circumtances and transactional distance in an distance education setting. Doktora tezi, Wayne State University, Detroit-Michigan.

Horzum, B. (2007). Internet tabanlı eğitimde etkileşimsel uzaklığın öğrenci başarısı, doyumu ve öz-yeterlik algısına etkisi. Doktora tezi, Ankara Üniversitesi Eğitim Bilimleri Enstitüsü, Ankara.

Jonassen, D. H. (1986). Hypertext principles for text and coursware design. Educational Psychologist, 21, $269-292$.

Kang, M., Choi, H. \& Park, S. (2007). Construction and validation of a social presence scale for measuring online learners' involvement. In C. Montgomerie \& J. Seale (Eds.), Proceedings of World Conference on Educational Multimedia, Hypermedia and Telecommunications (pp. 1829-1833). Chesapeake, VA: AACE.

Karasar, N. (2012). Bilimsel araştırma yöntemi: kavramlar, ilkeler, teknikler. Ankara: Nobel Yayın Dağıtım.

Kilic-Cakmak, E., Cebi, A., \& Kan, A. (2014). Developing a "social presence scale" for elearning environments. Educational Sciences: Theory \& Practice, 14(2), 755-768.

Kip, B. (2007). Çevrimiçi öğrenenlerin farklı destek ortamlarını kullanma sıklıklarıyla sosyal bulunuşluk algıları arasındaki ilişki. Yayımlanmamış yüksek lisans tezi. Anadolu Üniversitesi Sosyal Bilimler Enstitüsü, Eskişehir.

Leh, A. S. (2001). Computer-mediated communication and social presence in a distance learning environment. International Journal Of Educational Telecommunications, 7(2), 109-128.

Lowell, N. O. (2004). An investigation of factors contributing to perceived transactional distance in an online setting. Doktora tezi, University Of Northern Colorado, Greeley.

McLellan, H. (1999). Online education as interactive experience: some guiding models. Educational Technology, 39(5), 36-42.

Moore, M. (1983). On a theory of independent study in distance education: international perspectives. London: Croom Helm.

Moore, M. G. (1997). Theory of transactional distance. In Keegan, Theoretical Principles Of Distance Education, Routledge, 22-38.

Moore, M. G. \& Kearsley, G. (2011). Distance education: a systems view of online learning. Boston: Cengage Learning.

Nwankwo, V. I. (2013). The relationship between faculty perceptions andimplementation of elements of transactional distance theory and online web-based course completion rates. Doktora tezi, Florida International University, Miami.

Olpak, Y. Z. \& Kılıç Çakmak, E. (2009). E-öğrenme ortamları için sosyal bulunuşluk ölçeğinin uyarlama çalışması, Yüzüncü Yıl Üniversitesi Eğitim Fakültesi Dergisi, 6(1), 142-160.

Özkaya, M. (2013). Çevrimiçi öğrenme öğrencilerinin transaksiyonel uzaklık algısı, sorgulama topluluğu algısı ve öğrenme yaklaşımlarının akademik başarıları üzerindeki etkisi. Yüksek lisans tezi. Sakarya Üniversitesi Eğitim Bilimleri Enstitüsü, Sakarya.

Parker, R. E. \& Ingram, A. L. (2011). Considerations in choosing online collaboration systems: functions, uses, and effects. Journal Of The Research Center For Educational Technology, 7(1), 2-15.

Poza, M. I. C. (2011). A case of computer-mediated communication and multimedia integration: breaking classroom barriers with more input and opportunities to communicate. Northeast Conference On The Teaching Of Foreign Languages NECTFL.

Rockinson-Szapkiw, A. J., Baker, J. D., Neukrug, E., \& Hanes, J. (2010). The efficacy of computer mediated communication technologies to augment and support effective online helping profession education. Journal Of Technology in Human Services, 28(3), 161-177.

Rovai, A. P. (2002). Building sense of community at a distance. The International Review of Research in Open and Distributed 
Learning, 3(1).

So, H. J. (2008). When groups decide to use asynchronous online discussions: collaborative learning and social presence under a voluntary participation structure. Journal Of Computer Assisted Learning, 25(2), 143-160.

So, H. J. \& Brush, T. A. (2008). Student perceptions of collaborative learning, social presence and satisfaction in a blended learning environment: relationships and critical factors. Computers And Education, 51(1), 318-336.

Şimşek, A. (2000). Öğretim tasarımında yeni yaklaşımlar, Anadolu Üniversitesi Iletişim Bilimleri Fakültesi Dergisi, 17, 157-169.

Şimşek, A. (2012). Sosyal bilimlerde araştırma yöntemleri. Eskişehir: Anadolu Üniversitesi Açıöŏgretim Fakültesi Yayınları.

Tu, C. H. (2000). Strategies to increase Interaction in online social learning environments. Society For Information Technology ve Teacher Education International Conference. Proceedings of SITE.

Tu, C. H. \& Mclsaac M. (2002). The relationship of social presence and interaction in online classes, The American Journal of Distance Education, 16(3), 131-150.

Tüzün, H. , Alsancak-Sarıkaya, D. , Altıntaş-Tekin, A. \& Yaşar-Eren, S. (2016). Üç-boyutlu çok-kullanııılı sanal ortamlarda buradalı̆̆ın incelenmesi, Hacettepe Üniversitesi Eğitim Fakültesi Dergisi, 31(3), 475-490.

Üstündağ, T. M. (2012). Çevrimiçi öğrenme ortamlarında uyarlanmış sosyal etkileşim araçlarının öğrencilerin akademik başarılarına ve sosyal bulunuşluk algılarına etkisi. Doktora tezi. Gazi Üniversitesi Eğitim Bilimleri Enstitüsü, Ankara.

Whiteman, J.A.M. (2002). Interpersonal communication in computer mediated learning. <http://www.eric.ed.gov/PDFS/ ED465997> (2018, Aralık28)

Yıldırım, A. \& Şimşek, H. (2013). Sosyal bilimlerde nitel araştırma yöntemleri. Ankara: Seçkin Yayıncılık.

Yılmaz, R. \& Keser, H. (2015). İşlemsel uzaklık ölçeğinin uyarlama çalışması, Hacettepe Üniversitesi Eğitim Fakültesi Dergisi, 30(4), 91-105.

YIlmaz, K,G,F. (2017). Social presence and transactional distance as an antecedent to knowledge sharing in virtual learning communities. Journal Of Educational Computing Research, 55(6), 844-864.

Zhang, A. (2003). Transactional distance in web-based college learning environments: toward measurement and theory construction. Doktora tezi. Virginia Commonwealth University, Virginia. 